Saeculum Christianum

t. XXVII $\bullet 2 / 2020$

s. $158-168$

\author{
ADAM BULAWA ${ }^{1}$ \\ Wydział Nauk Historycznych \\ Uniwersytet Kardynała Stefana Wyszyńskiego, Warszawa \\ ORCID: 0000-0002-8064-306X
}

\title{
POLSCY WETERANI \\ REWOLUCJI WĘGIERSKIEJ (1848-1849) DOWÓDCAMI POWSTANIA STYCZNIOWEGO (1863-1864)
}

\author{
Polish veterans of the Hungarian Revolution (1848-1849) \\ as commanders of the January uprising (1863-1864) \\ Abstract
}

Veterans of the Hungarian so-called Spring of Nations (1848-1849) commanded over a dozen armed units in the January Uprising. The military art in several categories of the insurgent commanders from this background is analyzed on personal examples: a) being distinguished by successful campaigns; b) of a good level, but famous for one unaided confrontation; c) gradually gaining experience; d) being prevented by circumstances from demonstrating their full skills; e) having raised high expectations yet turning out a great disappointment.

Keywords: Hungarian Spring of Nations / Hungarian Revolution 1848-1849, January Uprising, insurgent commanders 1863-1864, partisan military art 1863-1864

\section{Streszczenie}

Weterani Węgierskiej Wiosny Ludów (1848-1849) dowodzili kilkunastoma oddziałami zbrojnymi Powstania Styczniowego. Na personalnych przykładach przeanalizowano sztukę wojenną kilku kategorii insurekcyjnych dowódców z tego proweniencyjnego kręgu: a) wyróżniających się udanymi kampaniami; b) na dobrym poziomie, lecz znanych z jednego samodzielnego starcia; c) stopniowo nabywających doświadczenia; d) tych, którym okoliczności uniemożliwiły zademonstrowanie pełni umiejętności; e) budzących wielkie oczekiwania i okazujących się wielkim rozczarowaniem.

Słowa kluczowe: Węgierska Wiosna Ludów/Rewolucja Węgierska 1848-1849, Powstanie Styczniowe, powstańcza kadra dowódcza 1863-1864, partyzancka sztuka wojenna 1863-1864

\footnotetext{
1 Dr Adam Buława, ur. 1971 w Warszawie, pracownik Katedry Historii Wojskowości Instytutu Historii WNHS UKSW; były dyrektor Muzeum Wojska Polskiego. Zainteresowania: dzieje wojskowości, walki o niepodległość (1795-1921), losy Polaków poza granicami kraju. E-mail: a.bulawa@uksw.edu.pl.
} 
_lak bojowy przyszłych dowódców polskiego zrywu niepodległościowego podczas $\checkmark$ Węgierskiego Powstania 1848-1849 omówiono w 1 części niniejszych rozważań ${ }^{2}$ Warto ocenić, jak polscy weterani Madziarskiej Rewolucji, którzy wówczas mieli okazję kierować oddziałami lub pododdziałami, spisali się podczas wojny partyzanckiej $1863 \mathrm{r}$.

Józef Wysocki to postać z pierwszego szeregu kandydatów do najwyższych stanowisk dowódczych, jeśli uwzględnić wyszkolenie, zaangażowanie w sprawę narodową, a przede wszystkim szlak bojowy oraz praktykę dowódczą bohatera Węgierskiej Rewolucji ${ }^{3}$. Już w Powstaniu Listopadowym dał się poznać jako dowódca baterii rakiet, natomiast podczas Węgierskiej Wiosny Ludów przebył ścieżkę awansu od majora-komendanta dwukompanijnego batalionu-legionu aż do generała honwedów, dowódcy korpusu i armii, udekorowanego orderem zasługi III i II klasy . Organizacja legionu na Węgrzech, a po części podobna próba w Turcji, była dlań mandatem do nadzorowania przygotowań, wspierającej lokalną insurekcję, tzw. wyprawy wołyńskiej. Krytycznie nastawiony oraz niekompetentny galicyjski komitet organizacyjny, pozbawiony wystarczającego nacisku ze strony Wysockiego przeciągał sprawę, o której dowiedzieli się zaborcy. Upadek insurekcji wołyńskiej i niedostateczny stan gotowości nie były dla poddanego presji Wysockiego wystarczającym argumentem do zaniechania ataku na przygraniczny Radziwiłłów (1-3 VII 1863) ${ }^{5}$. O jego niedostatecznej wierze w sukces świadczył przyjęty do realizacji plan, ograniczony do zajęcia ośrodka garnizonowego, potencjalnego punktu oporu przeciw nadchodzącym siłom nieprzyjacielskim, w oczekiwaniu na reaktywację powstania na Wołyniu. Oddziały Józefa Miniewskiego (500 pieszych) od północy, Franciszka Horodyńskiego (360 pieszych) od Krzemieńca i w centrum dowódcy przedsięwzięcia (800 pieszych, 200 jazdy) miały szturmować obsadzoną przez 500 Rosjan gen. Krejtera komorę graniczną. Przeciągnięcie przez Wysockiego przemarszu powstańców w letnim upale skutkowało po rozpętaniu się burzy przemoczeniem ubrań i zamoknięciem broni oraz kilkugodzinnym spóźnieniem w punkcie zbornym (2 VII). Mimo wieści o fiasku ataku oddziału Horodyńskiego oraz oddaleniu grupy Miniewskiego, Wysocki uderzył na silniejszą od spodziewanej, ukrytą za miejskimi murami załogę nieprzyjacielską, jednak szturm na przedmieście zakończył się ok. 14.00 wycofaniem insurgentów. Postój w podmiejskim lasku skutkował, wobec informacji o nadciągających posiłkach rosyjskich i niepewności co do oddziału Miniewskiego, powrotem

\footnotetext{
A. Buława, ,, Węgierski ślad”. Z Wiosny Ludów (1848-1849) na obszarze Korony św. Stefana do polskiego powstania (1863-1864), cz. 1, „Saeculum Christianum”, 23/2016, s. 191-207. Po publikacji ww. artykułu wydany został opracowany przez Istvana Kovacsa Honwedzi, emisariusze, legioniści. Stownik biograficzny polskich uczestników Wiosny Ludów na Węrzech 1848-1849, tłum. J. Snopek, Kraków 2016. Spośród bohaterów ww. artykułu biogramów doczekali się: Leon Czechowski, Edward Dunajewski, Franciszek Horodyński, Józef Jagmin, Antoni Jeziorański, Zygmunt Jordan, Karol Kalita, Walery Kozłowski, Walenty Lewandowski, Aleksander Matuszewicz, Zygmunt Miłkowski, Juliusz Nadmiller, Władysław Rucki, Stanisław Szumlański, Edmund Ślaski, Tomasz Wierzbicki, Leszek Wiśniowski, Józef Wysocki. Mimo kwerendy autora Słownika nie oznacza to, że pozostali komendanci nie walczyli „za wolność waszą i naszą”, a jedynie nie zachowały się materiały źródłowe w węgierskich archiwach.

3 Poświęcił mu biografię A. Szmyt (Generał Józef Wysocki w stużbie wolności Polaków i Węgrów, Olszyn 2001).

4 A. Buława, op. cit., s. 191, 194-199; I. Kovacs, op. cit., s. 762-763; E. Kozłowski, Legion Polski na Wegrzech 1848-1849, Warszawa 1983, s. 104, 134-136, 204-206, 211-212, 221, 237-238, 247; J. Wysocki, Pamiętnik dowódcy Legionu Polskiego na Węgrzech z czasów kampanii węgierskiej, Kraków 1888, s. 12, 47-48, 51-53, 58-61, 65.

5 G.I. Marachow, Polskoje wosstanije 1863 g. na Prawobierieżnoj Ukrainie, Kijew 1967, s. 202; S. Zieliński, Bitwy i potyczki, Rapperswyl 1913, s. 346-347; W. Przyborowski, Dzieje 1863 r., t. 3, Kraków 1897-1919, s. 295; F. Rawita-Gawroński, Rok 1863 na Rusi, t. 2, Lwów 1902, s. 148.
} 
za kordon ${ }^{6}$. Zanim został aresztowany przez austriacką policję, obwiniono o nieudolność i zdymisjonowano Wysockiego. Poza obiektywnymi okolicznościami (burza) nie dopisało zgranie trzech komendantów, wyszkolenie i morale podwładnych. Nie potrafiąc dostosować się do realiów wojny partyzanckiej, Wysocki zaniedbał rozpoznania, decyzja o szturmie nosiła znamiona desperacji, także podczas boju szukał śmierci. Nie bez winy pozostawali działacze lwowscy, zaniechano wymogów konspiracji, zawiedli pozostali dowódcy, a przede wszystkim wadliwa koncepcja wyprawy.

Franciszek Ksawery Horodyński przeżył chrzest bojowy jako ppor. 21 pułku piechoty armii powstańczej w 1831 r., zaś w Powstaniu Węgierskim mianowany został kapitanem i dowódcą 1. kompanii 3. batalionu Legionu Polskiego, a jego zastępcze dowodzenie całym batalionem w batalii temesvarskiej uhonorowano orderem zasługi III klasy ${ }^{7}$. Podczas Powstania Styczniowego w lipcu 1863 r., kierując częścią ekspedycji Józefa Wysockiego na Wołyń (360 podkomendnych), bez weryfikacji informacji o opuszczeniu Radziwiłłowa przez załogę, wbrew rozsądkowi i rozkazom, a mimo zmęczenia ludzi całonocnym marszem i zamoknięcia ładunków, nie czekając na pozostałe oddziały, z zamiarem zdobycia samodzielnej sławy wkroczył na rzekomo opustoszałe uliczki (2 VII 1863) ${ }^{8}$. Insurgenci dostali się pod ostrzał silniejszych niż zakładano obrońców. Uciekinierów wyłapano, inni wraz z komendantem położyli głowę. Ocalała garstka kawalerzystów. Za dezynwolturę przyszło Horodyńskiemu zapłacić wysoką cenę.

Leon Czechowski cieszył się zasłużoną sławą uczestnika wszystkich zrywów narodowowyzwoleńczych 1831-18489. Inaugurował Powstanie Listopadowe jako ppor. grenadierów gwardii aktywnie uczestniczący w Nocy Listopadowej, zakończył je w stopniu kapitana. Podczas niedoszłego zrywu powstańczego 1846 r. był niefortunnym dowódcą ochotników przewidzianych do uderzenia na austriacki garnizon w Tarnowie. W rewolucji węgierskiej 1848-1849 zajmował w stopniu majora stanowisko zwierzchnika piechoty i 2 . batalionu polskiego Legionu Siedmiogrodzkiego. Trudno o lepszą rekomendację dla nominacji na insurekcyjnego naczelnika lubelskich sił zbrojnych, któremu zalecono przemarsz zwerbowanego w Galicji oddziału (800 pieszych, 50 konnych) zza kordonu w głąb województwa. Dwutygodniowa kampania w marcu 1863 r. w Tarnogrodzkiem zweryfikowała nadmierne oczekiwania $^{10}$. Czechowski powiódł podwładnych na północ, lecz zawrócił w rejon nadgraniczny. Po informacji o nadciągających siłach rosyjskich zmienił lokalizację leśnego obozowiska pod Potokiem Dolnym, tak że wymiana ogniowa i konny manewr na prawym skrzydle kolumny kpt. Zawadzkiego (7 rot piechoty, szwadron ułanów, 100 kozaków - ok. 1700 żołnierzy) skutkowały odparciem napastników (20 III 1863). Umiejętnie wybrana lokalizacja nad rzeką powstańczego biwaku umożliwiła powrót na z góry upatrzone pozycje

\footnotetext{
6 W. Przyborowski, op. cit. 3, s. 295; F. Rawita-Gawroński, Rok 1863, t. 1, s. 148; E. Kozłowski, Zarys historii militarnej powstania styczniowego, w: Powstanie styczniowe. Wrzenie - Bój - Europa - Wizje, red. S. Kalembka, Warszawa 1990, s. 328; „Dziennik Powszechny”, 1863, nr 84, s. 1; „Czas”, 1863, nr 153, s. 1-2; „Doniesienie Rządu Narodowego", 3 VIII 1863.

7 I. Kovacs, op. cit., s. 232-233; J. Wysocki, op. cit., s. 131-145.

8 Jak w przypisie nr 6.

9 M. Tyrowicz, Czechowski Leon (1797-1888), w: Polski Słownik Biograficzny (dalej: PSB), t. 4, Kraków 1938, s. 314-315; I. Kovacs. op. cit., s. 107-109; J. Harlender, Leon Czechowski, w: tenże, Jarosław i jego ludzie, Jarosław 1937, s. 75-105.

10 R. Wójtowicz, Działalność Jana Żaplachty-Zapałowicza w powstaniu styczniowym, „Summarium. Sprawozdania Towarzystwa Naukowego KUL”, nr 6 (26) za r. 1977, Lublin 1979, s. 162.
} 
i dwukrotne odparcie wzmocnionych Rosjan (20 III 1863, Suszki). Zasadzka przygotowana na leśno-bagiennym terenie na przeważające, trzy pościgowe kolumny przyniosła powstrzymanie natarcia (21 III 1863, Huta Krzeszowska) ${ }^{11}$. W momencie gdy można było spędzić i oskrzydlić wroga, Czechowski zakomenderował odmarsz ku kordonowi, który przekroczono, opędzając się przed kozakami. Doszukując się okoliczności łagodzących w ocenie tego dowódcy, takich jak zamiar uzyskania kontyngentów uzbrojenia i żywności, obawa osamotnienia i rozbicia, minimalistyczne odczytanie rządowych zaleceń, trudno nie napiętnować asekuranctwa, wyrażającego się unikaniem starć - można było rozbijać po kolei nadchodzące kolumny, nie dopuszczając do ich zespolenia. Karygodne były zaniechanie środków ostrożności, bierność oraz zaniechanie rozpoznania.

Zygmunt Jordan uznawany był za jedną z ostatnich nadziei stronnictwa białych. Predestynowały go do tego służba w armii carskiej, udział w powstaniu krakowskim $1846 \mathrm{r}$., jak też zaszczytna służba w 44. batalionie rewolucyjnych honwedów na Węgrzech, gdzie został też adiutantem obejmującego dwukrotnie obowiązki Naczelnego Wodza gen. Henryka Dembińskiego, a za kierowanie brawurową obroną mostu na Cisie w bitwie pod Nowym Szegedynem zasłużył na powstańczy order zasługi III klasy ${ }^{12}$. Odznaczył się również w armii tureckiej podczas wojny krymskiej. Jako stacjonujący od połowy marca 1863 r. w Krakowie organizator tzw. korpusu krakowskiego i naczelnik wojskowy dwóch województw ponad kwartał przygotowywał operację zbrojną ${ }^{13}$. Potencjalny powstańczy dyktator dopracowywał nową taktykę (wkroczenie 7 oddziałów w ok. 2100-2800 ochotników), chociaż opóźnienie wynikało też z oczekiwania na interwencję mocarstw ${ }^{14}$. Idea ofensywy od Miechowa do Stopnicy przy wsparciu sąsiednich wojewódzkich dowództw powstańczych zawęziła się do pow. tarnowskiego, a ostatecznie w desancie przez Wisłę wzięły udział dwa bataliony po 400 ochotników, jeden pod dowództwem Jana Popiela-Chościakiewicza ${ }^{15}$. Na drugim brzegu rzeki, pod Komorowem, Jordan zaordynował uszykowanie kompanii do ataku (20 VI 1863) choć bezpośrednim dowódcą podczas boju był Jan Popiel. Udało się wyprzeć rotę piechoty rosyjskiej ze skraju wsi, jednak szturm załamał się, a po rozprawie z oddziałem Edwarda Dunajewskiego nadciągnęła kolejna rota (200 żołnierzy). Sformowanie czworoboków pomogło odeprzeć dwie szarże dragonów, lecz wieść o porażce Dunajewskiego i posiłki wzmacniające ponad dwukrotnie przeciwnika dopełniły klęski przypieczętowanej powrotem za kordon. Demoralizujące okazało się przeciąganie wyjścia, błędny wybór pory i miejsca lądowania. Wąskie koryto i niska woda rzeki, z bezleśnością po stronie austriackiej, wzmagały czuj-

11 S. Zieliński, op. cit., s. 85-86; W. Przyborowski, op. cit., t. 4, s. 172; F. Erlach, Partyzantka w Polsce w roku 1863, Warszawa 1960, s. 26, 81, 96; L. Weber von Ehrenzweig, Wyprawa Czachowskiego, w: W 40 rocznice powstania styczniowego 1863-1903, opr. J. Białynia-Chołodecki, Lwów 1903, s. 487; Urzędowy wykaz potyczek wojsk carskich w Królestwie Polskim w latach 1863-1864, wyd. L. Ratajczyk, „Studia i Materiały do Historii Wojskowości” (dalej: SiMdHW), 8/1962, z. 2, s. 282; „Wiadomości z pola bitwy”, 1863, nr 7/28 III, dodatek nadzwyczajny; „Czas”, 1863, nr 71, s. 1 ; nr 73, s. 1; nr 75, s. 1.

12 H. Wereszycki, Jordan Zygmunt, w: PSB, t. 11, Wrocław 1964-1965, s. 290; I Kovacs, op. cit., s. 272-274.

13 E. Kozłowski, Wyprawy wojenne z Krakowa w 1863 r., w: Kraków w powstaniu styczniowym, red. K. Olszański, Kraków 1968, s. 137, 140; A. Kunisz, Galicja a powstanie, „Rocznik Świętokrzyski”, 2/1971, s. 174; J.K. Janowski, Pamiętniki o powstaniu styczniowym, Lwów-Warszawa 1923-1931, t. 2, s. 187.

14 List Tarnowskiego do Siemieńskiego, w: Wyprawa komorowska w 1863 r., wyd. E. Kozłowski, B. Ratusiński, SiMdHW, 8/1964, z. 1, s. 289; W. Przyborowski, op. cit., t. 4, s. 242; E. Kozłowski, Wyprawy wojenne, s. 140.

15 W. Przyborowski, op. cit., t. 4, s. 249; S. Zieliński, op. cit., s. 171, E. Kozłowski, Wyprawy wojenne, s. 142; List Tarnowskiego do Siemieńskiego, s. 289-294.

16 Tamże, s. 293; S. Zieliński, op. cit., s. 171-172; Urzędowy wykaz, s. 295. 
ność pograniczników, płaskie błonia i brak pozycji obronnych przy odkryciu przygotowań i sąsiedztwie załóg rosyjskich tylko przy wysokiej klasie dowódcy, waleczności żołnierzy i szczęściu pozwalały przedrzeć się do kompleksu leśnego z pomocą akcji odciągającej. Insurgentów osłabił podział na dwa oddziały. Cała wyprawa przekreśliła aspiracje Jordana, obnażając niekompetencję w prowadzeniu wojny partyzanckiej.

Józef Jagmin to uczestnik większości XIX-wiecznych zrywów zbrojnych z udziałem Polaków przez blisko pół wieku (1831-1878) ${ }^{17}$. Wojnę polsko-rosyjską 1831 r. zakończył jako podoficer (partyzantka litewska, korpusy gen. Dembińskiego i Ramorino), za Wiosny Ludów wystąpił jako instruktor galicyjskiej gwardii narodowej, a w Rewolucji Węgierskiej z ppor. awansował na kapitana, dowodząc plutonem i kampanią Legionu Wysockiego (za męstwo bitewne udekorowany orderem zasługi III klasy) ${ }^{18}$. Latem 1863 r. był bezpośrednim komendantem batalionu Zygmunta Miłkowskiego przedzierającego się z Imperium Osmańskiego na Ukrainę. Zimą 1863/64 r. Józef Jagmin znalazł się w Galicji, gdzie otrzymał zwierzchnictwo nad niewielkim oddziałem. Po przejściu kordonu, ze względu na chorobę, pozostawił podwładnych Karolowi Rylskiemu. Pierwsze starcie po jego powrocie, przy niewielkiej przewadze insurgentów oznaczało odparcie rosyjskiego zespołu por. Kulikowa, dopiero odsiecz mjr. Bussowa wymusiła ich ucieczkę ku granicy (25 I 1864, Rudnik) ${ }^{19}$. Po połączeniu z jazdą kpt. Karoly-Kossowskiego i rozbitkami oddziału Wojciecha Komorowskiego, zaskoczony przez kilkakrotnie silniejszy zespół rosyjski (3 roty piechoty, szwadron dragonów, 1/2 sotni kozackiej - ok. 860 żołnierzy), w folwarku Sucha Wola Jagmin zarządził obronę zabudowań, po ich podpaleniu - przebicie się na bagnety w lasy (7 II 1864) ${ }^{20}$. Do marca wytrwał w Lubelskiem, po czym powrócił do Galicji. Choć z rocznika 1810, w roli partyzanckiego dowódcy spisywał się całkiem sprawnie.

Do najzdolniejszych dowódców insurekcyjnych należał Antoni Jeziorański, wywodzący się z pokolenia debiutującego podczas Wiosny Ludów, zrazu w roli instruktora krośnieńskiej gwardii narodowej, na Węgrzech zaś przebywając drogę od szeregowca do ppor. dowódcy plutonu ułanów i oficera kompanii piechoty ${ }^{21}$. Do armii tureckiej zaciągnął się w 1849 r., aby podczas 10-letniej służby m.in. zostać por. dywizji kozaków sułtańskich. Podczas kampanii na Mazowszu wsławił się napadem na Rawę (4 II 1863), skąd, dyskontując przewagę liczebności (374 strzelców, kosynierów i jeźdźców) oraz zaskoczenia wyparł 160 inwalidów i żandarmów ${ }^{22}$, a podczas marszu na południe zasadzką w folwarku pod

17 S. Kieniewicz, M. Tyrowicz, Jagmin Józef (1810-1877), w: PSB, t. 10, Wrocław 1962-1964, s. 318; I. Kovacs, op.cit., s. 252-253.

18 W trakcie wojny krymskiej w małoazjatyckim sztabie tureckim, a od 1855 r. w strukturach kozaków sułtańskich (kawaler odznaczeń tureckich i angielskich); podczas wojny rosyjsko-tureckiej (1877-1878) na czele europejskiej części Legionu Polskiego, poległ pod Kizilar.

19 S. Zieliński, op. cit., s. 120; E. Niebelski, Zmierzch powstania styczniowego w Lubelskiem i na Podlasiu (1863-1874), Lublin 1993, s. 64; Urzędowy wykaz, s. 291; „Dziennik Powszechny”, 1863, nr 29, s. 2.

20 S. Zieliński, op. cit., s. 121-122; W. Przyborowski, Ostatnie chwile powstania styczniowego, t. 1, Poznań 1887, s. 139; R. Hirsch, Z oddziału Jagmina (Wspomnienie), w: W 40 rocznice, s. 129; Urzędowy wykaz, s. 291; „Dziennik Powszechny", 1864, nr 44, s. 3.

21 E. Kozłowski, Jeziorański Antoni (1824-1882), w: PSB, t. 11, Wrocław 1964-1965, s. 215-216; I. Kovacs, op. cit., s. 268-269; A. Jeziorański, Pamiętniki jenerała Antoniego Jeziorańskiego od roku 1848 do roku 1863 , Lwów 1880.

22 W. Puś, Powiat rawski w okresie zaborów, w: Powiat rawski. Zarys dziejów do 1973 r., red. S.M. Zajączkowski, Łódź 1975, s. 245; P.J. Dekowski, Powstanie styczniowe w Tomaszowie Mazowieckim i sąsiednich pow. brzezińskim, rawskim i opoczyńskim, Tomaszów Mazowiecki 1935, s. 7-8; S. Zieliński, op. cit., s. 22-23; S. Gesket, 
Lubochnią (6 II 1863) na konnicę kolumny pościgowej mjr. Szokalskiego (4 roty piechoty, szwadron huzarów, sotnia kozaków - ok. 1100 żołnierzy) ${ }^{23}$. Operował rozrośniętą do ponad 200 konnych jazdą (cała jednostka liczyła ok. 875 ochotników), używając jej do potyczek kawaleryjskich (Studzianna, 10 II 1863; Przedbórz, 16 II 1863), bądź wsparcia piechoty (Żarnowiec, 20 II 1863) 24. Kolejny miesiąc wiązał się z koniecznością podporządkowania się naczelnikowi sandomierskich, później i krakowskich sił zbrojnych, Marianowi Langiewiczowi w Rapocicach (22 II 1863) ${ }^{25}$ i udziałem w jednej z największych batalii powstania pod Małogoszczem (24 II 1863) ${ }^{26}$. Podczas marszu zgrupowania przednie straże Jeziorańskiego starły się z forpocztą przeciwnika pod Uniejowem (28 II 1863) ${ }^{27}$. Obok walorów dowódcy ujawniły się wówczas u Jeziorańskiego arogancja oraz niechęć do drugiego z powstańczych dyktatorów, przejawiające się m.in. w podważaniu jego autorytetu, inspirowaniu intryg wewnątrz korpusu. Jeziorański, generał dyżurny sztabu Langiewicza, zaniedbał rozpoznania, co spowodowało utratę kontroli nad przebiegiem zwycięskiego, chaotycznego starcia pod Grochowiskami (18 III 1863) ${ }^{28}$. Jako wojskowy naczelnik woj. lubelskiego, kierujący wyprawą ok. 700 powstańców z Galicji, Jeziorański zamiast marszu w głąb Królestwa, m.in. wobec niedostatku amunicji, zajął pozycję przygraniczną. Wykorzystał gęsty i suchy bór oraz umocnienie zasiekami bazy partyzanckiej pod Kobylanką, aby przyjąć bitwę z płk. Sternbergiem (4 roty piesze, pluton ułanów, sotnia kozacka - ponad 900 żołnierzy), odwodowym uderzeniem skłaniając go do odwrotu i ścigając jazdą (1 V 1863) ${ }^{29}$. Kolejne kilka dni poświęcono na wzmocnienie fortyfikacji oraz uzupełnienie potencjału ludzkiego. Zaniecha-

$\overline{\text { Voennye dejstvija }} w$ Carstve Polskim v 1863 godu. Nacalo vozstanija (janvar, fevral i pervaja polovina marta), red. A. Puzyrevskij, Varsava 1894, s. 272; W. Przyborowski, Dzieje 1863 r., t. 1, s. 245; A. Jeziorański, Pamiętniki jenerała. Powstanie r. 1863, t. 2, Lwów 1913, s. 191; J. Sawicki-Stella, Ludzie $i$ wypadki z 1861-1865, Lwów 1894, t. 1, s. 85; Urzędowy wykaz, s. 303; „Wiadomości z pola bitwy”, 1863, nr 1; „Czas”, 1863, nr 32, s. 1.

23 J. Kukulski, Z dziejów powstania styczniowego w Piotrkowskiem, Piotrków Trybunalski 1991, s. 2; W. Puś, op. cit., s. 246; P.J. Dekowski, op. cit., s. 9-10; A. Sokołowski, Powstanie styczniowe, Warszawa 1921, s. 212; S. Zieliński, op. cit., s. 23; W. Przyborowski, Dzieje 1863, t. 1, s. 552; A. Gesket, op. cit., s. 273; A. Jeziorański, Pamiętniki jenerała, t. 1, s. 177, 193; Urzędowy wykaz, s. 303; „Wiadomości z pola bitwy”, 1863, nr 1, nr 2.

24 H. Rzadkowska, Marian Langiewicz, Warszawa 1967, s. 127; S. Zieliński, op. cit., s. 161-162; W. Przyborowski, Dzieje 1863 r., t. 1, s. 455; S. Szulc, Pamiętnik księdza kapelana, w: Polska w walce 1863-1864, red. A. Giller, t. 1, Paryż 1868, s. 39; A. Jeziorański, Pamiętniki jenerała, t. 2, s. 183.

25 J. Boniecki, Ważniejsze walki partyzanckie w guberni radomskiej, „Rocznik Świętokrzyski”, 1971, t. 2, s. 110; A. Gesket, op. cit., s. 381.

26 J. Boniecki, op. cit., s. 111; S. Zieliński, op. cit., s.162; J. Długosz, Akcja Langiewicza przed dyktatura, „Przegląd Narodowy”, 11/1913, nr 1, s. 72; W. Przyborowski, Dzieje 1863 r., t. 1, s. 471; S. Gesket, op. cit., s. 79; H. Rzadkowska, op. cit., s. 131-132; A. Jeziorański, Pamiętniki jenerała, t. 1, s. 202-208; D. Pietrzykowski, Dionizy Czachowski, Warszawa 1988, s. 91-97; W. Caban, Z dziejów powstania styczniowego w rejonie Gór Świętokrzyskich, Kraków 1989, s. 69-70; A. Borkiewicz, Działania Langiewicza przed dyktatura, SiMdHW, 8/1962, z.2, s. 261-265; Urzędowy wykaz, s. 293; J.K. Janowski, op. cit., t. 1, s. 226; A. Zdanowicz, Od Małogoszczy do Goszczy, w: W 40 rocznice, s. 538; Z. Sulima, Wspomnienia ułana z 1863 r., Poznań 1874-1875, s. 46; J. Sawicki- Stella, Ludzie, t. 1, s. 93; L. Grzybowski, Opis powstania polskiego w r. 1863 w woj. krakowskim, Kielce 1994, s. 28-31; „Wiadomości z pola bitwy”, 1863, nr 3, 5, 8, 10; „Czas”, 1863, nr 49, s. 3.

27 S. Zieliński, op. cit., s. 163; A. Zdanowicz, op. cit., s. 10; „Czas”, 1863, nr 50, s. 3, nr 52, s. 2.

28 S. Orzeł, Bitwa pod Grochowiskami, „Przegląd Historyczny”, 62/1972, z. 3, s. 449-475; H. Rzadkowska, op. cit., s. 277-280; Urzędowy wykaz, s. 293; L. Grzybowski, op. cit., s. 43-45.

29 E. Kozłowski, Od Węrowa do Opatowa. 3 II 1863-22 II 1864. Wybrane bitwy z powstania styczniowego, Warszawa 1962, s. 105-110; S. Zieliński, op. cit., s. 88; W. Przyborowski, Dzieje 1863 r., t. 1, s. 186; A. Jeziorański, Pamiętniki jenerała, t. 2, s. 47; Urzędowy wykaz, s. 383; „Wiadomości z pola bitwy”, 1863, 11 V, 29 V; „Czas”, 1863, nr 104, s. 1; Wspomnienia kapitana Wiśniewskiego, w: Polska w walce, s. 303; T. Żychliński, Wspomnienia z roku 1863, Poznań 1888, s. 91. 
nie przemarszu w głąb kraju usprawiedliwia zamiar odparcia spodziewanego natarcia (co zwiększyłoby pole manewru), nadto wieści o nadciągających kolumnach wroga. Jeziorański sprawnie kierował odporno-zaczepnym bojem w oparciu o pozycję terenową, reagował na zmiany sytuacji, m.in. zabezpieczając rezerwami słaby punkt linii obronnych przy granicy (6 $\mathrm{V} 1863)^{30}$. Ocenę dowódcy podnosi udział w ataku na bagnety. Wiktorię okupiono stratami, psychicznym wyczerpaniem i świadomością kolejnej koncentracji nieprzyjacielskich wojsk. Przejście kordonu z zamiarem powrotu w innym punkcie granicznym wywołało dezercję podwładnych. Porażka 100-osobowej partii Jeziorańskiego pod Hutą Krzeszowską (11 V 1863) wynikała z nieubezpieczenia obozu, zaskoczonego atakiem awangardy kolumny mjr. Ogolina, oraz rekonesansu, podczas którego dowódca został odcięty od głównych sił, kontuzjowany, pozbawiony wpływu na przebieg walki. Mimo uniewinnienia przez sąd wojskowy, pozbawiono Jeziorańskiego funkcji dowódczych.

Zygmunt Miłkowski to kolejny uczestnik Powstania Węgierskiego, wspinający się wówczas po szczeblach drabiny awansu od szeregowca do ppor., dowódcy plutonu w Legionie Polskim $^{31}$. W lipcu 1863 r. wyznaczony został do specjalnego zadania, przemarszu tzw. oddziału wschodniego Wojska Polskiego z tureckiej Bułgarii (Tulcza) poprzez księstwa naddunajskie na Podole ${ }^{32}$. Obok pomocy dla walczącego kraju, spodziewano się korzystnych dla sprawy polskiej, międzynarodowych komplikacji. Miłkowski zmagał się z masą problemów (niewielkie fundusze organizacyjne, mikroskopijne rozmiary legionu - 213 ochotników, stan techniczny uzbrojenia). Wydał odezwę, zamieszczoną w rumuńskiej prasie i rozbił 2 posterunki pograniczne. Oddziały rumuńskie obserwowały intruzów, aż do złożenia im propozycji oddania broni po przekroczeniu rzeki granicznej. Wybór pozycji w międzygórskiej dolinie pod Konstanglią eksponował obronne walory: oparcie się o ogród i folwark, skrzydłem ugrupowania o rzekę i asekurację drugiego odwodem (13 VII 1863) ${ }^{33}$. Miłkowski kontrolował przebieg walki z oddziałem płk. Calinescu, używając odwodu, gdy jazda przeciwnika wdarła się w lukę szyku bojowego, manewrując kompanią zagrożoną oskrzydleniem (uniknięcie i zamarkowanie przeciwoskrzydlenia) przy prowadzeniu walki w centrum przez wyszkolonych, wyposażonych w dalekosiężne karabiny ochotników. Ponieważ taktyczny sukces nie rokował powodzenia strategicznego, wobec nadciągających kolumn rumuńskich

\footnotetext{
30 E. Kozłowski, Od Węrowa do Opatowa, s. 113-118; S. Zieliński, op. cit., s. 88; W. Przyborowski, Dzieje 1863 r., t. 4, s. 195; A. Jeziorański, Pamiętniki jenerała, t. 1, s. 111; T. Żychliński, Wspomnienia, s. 91; J. Sawicki-Stella, Ludzie, t. 1, s. 176; K. Lange, Z pamiętników szarego ułana, w: Spiskowcy i partyzanci 1863 r., red. S. Kieniewicz, Warszawa 1967, s. 666-674; W. Wiśniewski, Wspomnienia kapitana wojsk polskich z r. 1863, Lipsk 1866, s. 304; „Wspomnienia z pola bitwy”, 1863, nr 11.

31 S. Kieniewicz, M. Małecki, Zygmunt Miłkowski (1824-1915), w: PSB, t. 22, Wrocław 1976, s. 263-268; I. Kovacs, op. cit., s. 467-469; Miłkowski Z., Od kolebki przez życie, Kraków 1936-1937.

32 K. Dopierała, Emigracja polska w Turcji w XIX i XX w., Lublin 1988, s. 255-265; tenże, Rok 1863 i Polacy w Imperium Osmańskim i Krajach Bałkańskich, „Przegląd Polsko-Polonijny”, 2012, nr 4, z. 2, s. 167-169; K.M. Willaume, Zygmunt Miłkowski (1824-1915) w powstaniu styczniowym, „Annales UMCS”, vol. LXVII/2012, z. 2, sectio F, Instytut Historii UMCS, s. 56-61; F. Rawita-Gawroński, op. cit., t. 1, s. 241-249.

33 K. Dopierała, Polska emigracja na Wschodzie, s. 133-135; K. Dach, Polityczne i militarne aspekty polsko-rumuńskiego starcia zbrojnego w lipcu 1863 r., „Studia Historyczne”, 18/1985, z. 4, s. 549-552; S. Zieliński, op. cit., s. 347-348; W. Przyborowski, Dzieje 1863 r., t. 3, s. 315; Z. Miłkowski, W Galicji i na Wschodzie, Przyczynek do dziejów powstania 1863 r., Poznań 1880, s. 130-135, 142-156; tenże, Opowiadanie polskiego żolnierza o wyprawie z Tulczy, w: Polska $w$ walce, s. 251; K. Brzozowski, Bitwa pod Konstanglia, w: W 40 rocznice, s. 795; „Czas”, 1863, nr 164, s. 3, nr 170, s. 2 (raport Miłkowskiego).
} 
złożono broń, większość internowanych przedarła się w Lubelskie ${ }^{34}$. Miłkowski metodycznie realizował zasady sztuki wojennej, co mimo słabego wyszkolenia i wyposażenia Rumunów, przy ich kilkukrotnej przewadze, warto odnotować.

Julian Nadmiller w 1848 r. z krakowskiej gwardii narodowej przedostał się na rewolucyjne Węgry, gdzie znalazł się w Legionie Wysockiego i w roli plutonowego formacji ułańskiej Władysława Ponińskiego ${ }^{35}$. Podczas Powstania Styczniowego dwukrotnie przejmował dowództwo nad formacjami konnymi: u schyłku lata 1863 r. w Augustowskiem oraz zimą w Mazowieckiem. Krążąc po Łomżyńskiem na czele połączonych trzech partii insurekcyjnych, ścierał się z wrogiem: napad przeważającej rosyjskiej kolumny ruchomej (ułani, kozacy, objeszczycy) na jego dwa szwadrony po trzykrotnym zwarciu zakończyła rejterada (Sanie, 3 IX 1863) ${ }^{36}$, a potyczka patroli rozwinęła się w starcie kawaleryjskie, zakończone uporządkowanym odwrotem (Brzeźnica, 7 IX 1863) ${ }^{37}$. Po przejęciu dowodzenia nad ok. 200-konnym oddziałem Dzieci Warszawy poprowadził rajd rozpoczęty nocną utarczką pod Rawą z 80 grenadierami i 70 kozakami (10 XII 1863) ${ }^{38}$, a następnie (przy zmieniających się uczestnikach walk po stronie rosyjskiej) trzydobowym pościgiem na dystansie $192 \mathrm{~km}$. Ostatni bój oddziału Nadmillera pod Życkiem, polegający na szarżach odpierających zespół konny sztabskpt. Poznańskiego i mjr. Kiryjewa (rota grenadierów, szwadron ułanów, 15 kozaków - ok. 385 żołnierzy), zakończył się przy znacznych stratach przedarciem się nad rzekę (13 XII 1863) $)^{39}$. Pozytywną notę sprawnego dowódcy powstańczej jazdy obniżyło Nadmillerowi opuszczenie podwładnych w połowie grudnia.

\section{Podsumowanie}

Na pytanie, czy podczas Powstania Styczniowego udało się zdyskontować po 15 latach umiejętności bojowe z 1848-1849-es forradalom és szabadságharc, odpowiedź nie jest jednoznaczna. Józef Wysocki nie potrafił wykorzystać specjalności Legionu Polskiego 18481849, czyli umiejętności zdobywania miejscowości podczas szturmu ośrodka miejskiego w 1863 r. Zygmunt Jordan, który w 1848 r. zasłynął w walkach obronnych nad rzeką, nie

\footnotetext{
34 J. Demel, Aleksander Jan Cuza, książe Rumunii, Wrocław 1977, s. 149, 152; K. Dach, op. cit., s. 550. Według różnych danych stan osobowy strony rumuńskiej to maksimum 1260 piechoty i 60 jazdy, minimum - 800 żołnierzy. 35 E. Kozłowski, Natmiller (Nadmiller) Julian (1823-1903), w: PSB, t. 22, s. 618-619; I. Kovacs, op. cit., s. 487-488 .

36 A. Chankowski, Powstanie styczniowe w Augustowskiem, Warszawa 1972, s. 142; Z. Kolumna, Pamiatka dla rodzin polskich. Krótkie wiadomości o straconych na rusztowaniach, poleglych, zmarlych na wygnaniu syberyjskim i tułactwie ofiar z 1861-1865 r., Kraków 1868, t. 1, s. 73-75, 234; J. Długosz, Oddziały powstańcze 1863 r. w guberni grodzieńskiej, „Przegląd Narodowy”, 1912, s. 80-84; Zeznania Jana Kozietta-Poklewskiego, w: Ruch rewolucyjny na Litwie i Białorusi 1861-1862, oprac. L. Arżajew, S. Bajkow, Moskwa 1969, s. 180-181; P. Powierza, Wspomnienia z powstania 1863 r., Białystok 1996, s. 31, 33-34; S. Zieliński, op. cit., s. 265-270, 334-335; I. Aramowicz, Marzenia. Pamiętnik o ruchu partyzanckim w województwie grodzieńskim w 1863 i 1864 r., w: Zapomniane wspomnienia (Powstanie 1863 r.), opr. E. Kozłowski, Warszawa 1981, s. 73; Urzędowy wykaz, s. 323; „Czas”, 1863 , nr 219, s. 2 (raport Nadmillera).

37 Urzędowy wykaz, s. 323; „Czas”, 1863, nr 219, s. 2 (raport Nadmillera), nr 230, s. 2; I. Aramowicz, op. cit, s. 81.

38 L. Ratajczyk, Polska wojna partyzancka 1863-1864. Okres dyktatury Romualda Traugutta, Warszawa 1966, s. 204, S. Zieliński, op. cit., s. 51-52; Dzieci Warszawskie. Dzieje oddziału skreślone przez naocznego świadka, „Słowo Polskie”, 1913, nr 46, s. 7; L. Żychliński, Pamiętniki bylego dowódcy Dzieci Warszawskich i bytego naczelnika sił zbrojnych powiatów warszawskiego i rawskiego, Poznań 1885, s. 197.

39 S. Zieliński, op. cit., s. 52; Dzieci Warszawskie, „Słowo Polskie”, 1913, nr 46, s. 7; L. Żychliński, op. cit., s. 197; Urzędowy wykaz, s. 313; „Chwila”, 1864, nr 1, s. 1 (raport Bartczaka).
} 
zdał egzaminu podczas insurekcyjnej ekspedycji za Wisłę. Kampania Leona Czechowskiego, mimo skutecznych obron obozów powstańczych oraz leśnej zasadzki zakończyła się powrotem za kordon. Inni spisali się lepiej, choć istotne było tutaj dodatkowe przygotowanie praktyczne i teoretyczne (Jeziorański - armia turecka). Trudno jednoznacznie stwierdzić, czy uczestnicy regularnych zmagań wojennych z habsburską Austrią i jej sojuszniczką Rosją, jako grupa kadrowa wyróżniali się specjalnym kunsztem dowódczym. Ostatecznie decydowały indywidualne predyspozycje.

\section{Bibliografia}

\section{Źródla}

Aramowicz I., Marzenia. Pamiętnik o ruchu partyzanckim w województwie grodzieńskim w 1863 i 1864 r., w: Zapomniane wspomnienia (Powstanie 1863 r.), opr. E. Kozłowski, Warszawa 1981, s. 10-94.

Brzozowski K., Bitwa pod Konstanglia, w: W 40 rocznice powstania styczniowego 1863-1903, 1863-1903, opr. J. Białynia-Chołodecki, Lwów 1903, s. 85-89.

„Chwila”, 1864.

„Czas”, 1863.

„Doniesienie Rządu Narodowego”, 1863.

Dzieci Warszawskie, Dzieje oddziału skreślone przez naocznego świadka, „Słowo Polskie”, 1913, nr 46, s. 7.

„Dziennik Powszechny”, 1863-1864.

Erlach F., Partyzantka w Polsce w roku 1863, Warszawa 1960.

Gesket S., Voennye dejstvija w Carstve Polskim v 1863 godu. Nacalo vozstanija ((janvar, fevral i pervaja polovina marta), red. A. Puzyrevskij, Varsava 1894.

Grzybowski L., Opis powstania polskiego w r. 1863 w woj. krakowskim, Kielce 1994.

Hirsch R., Z oddziatu Jagmina. Wspomnienie, w: W 40 rocznice powstania styczniowego 1863-1903, opr. J. Białynia-Chołodecki, Lwów 1903, s. 128-129

Janowski J.K., Pamiętniki o powstaniu styczniowym, Lwów-Warszawa 1923-1931.

Jeziorański A., Pamiętniki jenerała. Powstanie r. 1863, Lwów 1913.

Kolumna Z., Pamiątka dla rodzin polskich. Krótkie wiadomości o straconych na rusztowaniach, polegtych, zmartych na wygnaniu syberyjskim i tułactwie ofiar z 1861-1865, t. 1, Kraków 1868.

Lange K., Z pamiętników szarego ułana, w: Spiskowcy i partyzanci 1863 r., red. S. Kieniewicz, Warszawa 1968, s. 666-674.

Miłkowski Z., W Galicji i na Wschodzie. Przyczynek do dziejów powstania 1863 r., Poznań 1880.

Miłkowski Z., Opowiadanie polskiego żolnierza o wyprawie z Tulczy, w: Polska w walce, Zbiór pamiętników z czasów naszego wyjarzmiania, red. A. Giller, t. 1, Paryż 1868, s. 249-253.

Powierza P., Wspomnienia z powstania 1863 r., Białystok 1996.

Sawicki-Stella J., Ludzie i wypadki z 1861-1865 r., Lwów 1894.

Sulima Z., Wspomnienia ułana z 1863 r., Poznań 1874-1875.

Szulc S., Pamiętnik księdza kapelana, w: Polska $w$ walce. Zbiór pamiętników z czasów naszego wyjarzmiania, wyd. A. Giller, t. 1, Paryż 1868, s. 65-142. 
Urzędowy wykaz potyczek wojsk carskich w Królestwie Polskim w l. 1863-1864, wyd. L. Ratajczyk, „Studia i Materiały do Historii Wojskowości”, 8/1962, z. 2, s. 275-324.

Weber von Ehrenzweig L., Wyprawa Czachowskiego, w: $W 40$ rocznicę powstania styczniowego. 1863-1903, opr. J. Białynia Chołodecki, Lwów 1903, s. 487-490.

„Wiadomości z pola bitwy”, 1863.

Wiśniewski W., Wspomnienia kapitana wojsk polskich z r. 1863, Lipsk 1866.

Wysocki J., Pamiętnik jenerata Wysockiego, dowódcy Legionu Polskiego na Węgrzech w 1848 r., Kraków 1898.

Wspomnienia kapitana Wiśniewskiego, w: Polska w walce. Zbiór pamiętników z czasów naszego wyjarzmiania, wyd. A. Giller, t. 1, Paryż 1868, s. 303-304.

Wyprawa komorowska w 1863 r., wyd. E. Kozłowski, B. Ratusiński, „Studia i Materiały do Historii Wojskowości”, 10/1964, z. 1, s. 268-294.

Zdanowicz A., Od Małogoszcza do Goszczy, w: W 40 rocznice powstania styczniowego 1863-1903, opr. J. Białynia-Chołodecki, Lwów 1903, s. 538-545.

Zeznania Jana Kozietta-Poklewskiego, w: Ruch rewolucyjny na Litwie i Białorusi 1861-1862, oprac. L. Arżajew, S. Bajkow, Moskwa 1969, s. 180-181.

Zienkiewicz K., Wspomnienia powstańca 1863 r., Warszawa 1932.

Żychliński L., Pamiętniki byłego dowódcy Dzieci Warszawskich oraz naczelnika sił zbrojnych powiatów rawskiego i warszawskiego, Poznań 1885.

\section{Opracowania}

Boniecki J., Ważniejsze walki partyzanckie w guberni radomskiej, „Rocznik Świętokrzyski”, 1971, t. 2, s. 104-105.

Borkiewicz A., Działania Langiewicza przed dyktatura, „Studia i Materiały do Historii Wojskowości”, 8/1962, z. 2, s. 203-273.

Buława A., ,,Węgierski ślad”. Z Wiosny Ludów (1848-1849) na obszarze Korony św. Stefana do polskiego powstania (1863-1864), cz. 1, „Saeculum Christanum”, 23/2016, s. 191-207.

Caban W., Z dziejów powstania styczniowego w rejonie Gór Świętokrzyskich, Kraków 1989.

Chankowski S., Powstanie styczniowe w Augustowskiem, Warszawa 1972.

Dach K., Polityczne i militarne aspekty polsko-rumuńskiego starcia zbrojnego w lipcu 1863 r., „Studia Historyczne”, 18/1985, z. 4, s. 539-558.

Dekowski P.J., Powstanie styczniowe w Tomaszowie Mazowieckim i sqasiednich pow. brzezińskim, rawskim i opoczyńskim, Tomaszów Mazowiecki 1935.

Demel J., Aleksander Jan Cuza, książę Rumunii, Wrocław 1977.

Długosz J., Akcja Langiewicza przed dyktatura, „Przegląd Narodowy”, 9/1913, nr 1, s. 62$-81 ; \mathrm{nr}$ 4, s. 373-390.

Długosz J., Oddziały powstańcze w guberni grodzieńskiej, „Przegląd Narodowy”, 8/1912, nr 1, s. 80-84.

Dopierała K., Emigracja polska w Turcji w XIX i XX w., Lublin 1988.

Dopierała K., Rok 1863 i Polacy w Imperium Osmańskim i krajach bałkańskich, „Przegląd Polsko-Polonijny", 2012, nr 4, z. 2, s. 157-174.

Harlender J., Leon Czechowski, w: tenże, Jarosław i jego ludzie, Jarosław 1937, s. 75-99.

Kieniewicz S., Małecki M., Miłkowski Zygmunt (1824-1915), w: Polski Stownik Biograficzny, t. 21, Wrocław 1976, s. 263-268. 
Kieniewicz S., Tyrowicz M., Józef Jagmin (1810-1877), w: Polski Słownik Biograficzny, t. 10, Wrocław 1962-1964, s. 318.

Kovacs I., Honwedzi, emisariusze, legioniści. Słownik biograficzny polskich uczestników Wiosny Ludów na Wegrzech 1848-1849, tłum. J. Snopek, Kraków 2016.

Kozłowski E., Generał Józef Hauke-Bosak, Warszawa 1973.

Kozłowski E., Jeziorański Antoni (1821-1882 ), w: Polski Słownik Biograficzny, t. 11, Wrocław 1964-1865, s. 215-216.

Kozłowski E., Legion Polski na Wegrzech 1848-1849, Warszawa 1983.

Kozłowski E., Nathmiller Julian (1823-1903), w: Polski Słownik Biograficzny, t. 23, Wrocław 1978, s. 618-619.

Kozłowski E., Od Wegrowa do Opatowa. 3 II 1863 - 22 II 1864. Wybrane bitwy z powstania styczniowego, Warszawa 1962.

Kozłowski E., Wyprawy wojenne z Krakowa w 1863 r., w: Kraków w powstaniu styczniowym, red. K. Olszański, Kraków 1968, s. 95-154.

Kozłowski E., Zarys historii militarnej powstania styczniowego, w: Powstanie styczniowe. Wrzenie - Bój-Europa - Wizje, red. S. Kalembka, Warszawa 1990.

Kukulski J., Z dziejów powstania styczniowego w Piotrkowskiem, Piotrków Trybunalski 1991.

Kunisz A., Galicja a powstanie, „Rocznik Świętokrzyski”, 2/1971, s. 157-202.

Marachow G.I., Polskoje wosstanije 1863 g. na Prawobierieżnoj Ukrainie, Kijew 1967.

Niebelski E., Zmierzch powstania styczniowego w Lubelskiem i na Podlasiu (1863-1864), Lublin 1993.

Orzeł S., Bitwa pod Grochowiskami, „Przegląd Historyczny”, 62/1972, z. 3, s. 449-475.

Pietrzykowski D., Dionizy Czachowski, Warszawa 1988.

Przyborowski W., Dzieje 1863 r., t. 1-5, Kraków 1897-1919.

Przyborowski W., Ostatnie chwile powstania styczniowego, Poznań-Kraków 1887.

Puś W., Powiat rawski w okresie zaborów, w: Powiat rawski. Zarys dziejów do końca 1973 r., red. S.A. Zajączkowski, Łódź 1975, s. 198-295.

Ratajczyk L., Polska wojna partyzancka 1863-1864. Okres dyktatury Romualda Traugutta, Warszawa 1966.

Rawita-Gawroński F., Rok 1863 na Rusi, t. 1-2, Lwów 1902.

Rzadkowska H., Marian Langiewicz, Warszawa 1967.

Sokołowski A., Powstanie styczniowe, Warszawa 1921.

Szmyt A., Generał Józef Wysocki w stużbie wolności Polaków i Węrów, Olsztyn 2001.

Tyrowicz M., Czechowski Leon (1797-1888), w: Polski Słownik Biograficzny, t. 4, Wrocław 1938, s. 314-315.

Wereszycki H., Zygmunt Jordan (1824-1866), w: Polski Słownik Biograficzny, t. 10, Wrocław 1962-1964, s. 290.

Willaume M., Zygmunt Miłkowski (1824-1915) w powstaniu styczniowym, „Annales UMCS”, 67/2012, z. 2, sectio F, Instytut Historii UMCS, s. 49-61.

Wójtowicz R., Działalność Jana Żaplachty-Zapałowicza w powstaniu styczniowym, „Summarium. Sprawozdania Towarzystwa Naukowego KUL", nr 6(26) za r. 1977, 1979, s. 161-164.

Zieliński S., Bitwy i potyczki 1863-1864, Rapperswil 1913. 